\title{
A REVIEW OF THE ECOLOGY OF GRAPEVINE LEAFROLL ASSOCIATED VIRUS TYPE 3 (GLRaV-3)
}

\author{
J.G. CHARLES ${ }^{1}$, D. COHEN ${ }^{1}$, J.T.S WALKER ${ }^{2}$, S.A. FORGIE ${ }^{1}$, \\ V.A. BELL ${ }^{2}$ and K.C. BREEN ${ }^{2}$ \\ ${ }^{1}$ HortResearch, Private Bag 92169, Auckland, New Zealand \\ ${ }^{2}$ HortResearch,Private Bag 1401, Havelock North, New Zealand \\ Corresponding authors: jcharles@hortresearch.co.nz.or \\ jwalker@hortresearch.co.nz
}

\begin{abstract}
Grapevine leafroll disease in New Zealand is predominantly caused by the ampelovirus GLRaV-3, which is vectored between vines by up to three species of mealybugs (Pseudococcus spp.). However, global understanding of the transmission and spread of GLRaV-3 remains limited, and does not definitively show how to successfully manage the disease in New Zealand. The disease is a manifestation of a complex relationship between the virus, vine and vectors, each component of which is interdependent on the other two. The review suggests that a full understanding of the disease will require research and operational input from plant virologists, entomologists, vine physiologists, pest controllers, vineyard managers, grapevine breeders/improvers and winemakers. Such a wide range of expertise should ensure that the factors behind the spread of the disease over time (its epidemiology) are accurately determined, and that effective management solutions are delivered over the course of decades.
\end{abstract}

Keywords: economic and vineyard impact, mealybug vectors, transmission ecology, disease management.

\section{INTRODUCTION}

A key goal of the New Zealand Wine Industry is to control the spread and impact of virus diseases, particularly Grapevine Leafroll associated Virus type 3 (GLRaV-3), in New Zealand vineyards. A recent survey of 'winegrowers' (Bonfiglioli \& Stewart 2005) showed that respondents held a wide divergence of views on the importance of GLRaV-3 and clearly indicated that more could be done to inform the industry about the nature and impacts of GLRaV-3, and how it might best be managed (Nimmo-Bell 2005). In response, New Zealand Winegrowers (NZWG) commissioned a review of the national and international science and technical literature on this grapevine virus (Charles et al. 2006). A goal was to provide a platform for a long-term industry programme to control the spread and impact of GLRaV-3. An overview and summary of the review submitted to NZWG is presented here.

Literature review databases (e.g. CAB Abstracts, VITIS VEA, Agricola and Web of Science), key technical reports to New Zealand's Ministry for Agriculture and Forestry, the wine industry and NZWG, and internet-based reviews were searched for keywords associated with grapevine virus diseases. Although focused on GLRaV-3, the review considered studies of other grapevine viruses, or other plant viruses, that provided useful insights into the ecology of GLRaV-3. Mealybugs are now acknowledged as the dominant vectors of GLRaV-3. An appropriate selection of the ca 2000 scientific references on mealybug biology and control, judged to make a significant contribution to knowledge of mealybugs in relation to plant viruses and grapes, was reviewed. Data are presented in four sections, to reflect different components of grapevine leafroll 
disease: the GLRaV-3 virus; impacts of GLRaV-3 infection in the vineyard; GLRaV-3 vectors and the ecology of transmission; and management options in vineyards to limit GLRaV-3 infection and spread.

\section{THE GLRaV-3 VIRUS}

Grapevine leafroll disease has probably been in New Zealand for more than 100 years (Bragato 1902), although it was first positively reported in 1964 (McKissock 1964). At this time, leafroll symptoms were commonly seen in European Vitis vinifera, but not in US hybrids or rootstock species (Chamberlain 1967). During the early 1970s, the Department of Scientific and Industrial Research (DSIR) started to investigate the vine pathology of leafroll disease, and released "virus-free" vines resulting from thermotherapy. Recognition of the similarity of disease symptoms to potassium deficiency provided an early indication of the mode of pathology of the virus (Over de Linden \& Chamberlain 1970; Thomas 1976).

Grapevine leafroll disease was first associated with closterovirus-like particles in the mid-1980s. Serological techniques identified a number of distinct serotypes, and grapevine leafroll disease in New Zealand was reliably associated almost exclusively with GLRaV-3 (Petersen \& Jordan 1992; Bonfiglioli et al. 2001). Monoclonal antibodies are now routinely used to achieve high-throughput, sensitive detection of GLRaV-3. Recent advances in virus taxonomy (based on molecular structure) have clarified the relationships between different grapevine viruses, and GLRaV-3 has been placed in the genus Ampelovirus of the virus family Closteroviridae. Different groups of viruses in this family have been characterised, at least in part, by their transmission by different groups of insects. Ampelovirus is transmitted exclusively by mealybugs and scale insects (Martelli et al. 2002). Evidence for different strains of GLRaV-3 comes from two analyses of sequence variation in different isolates of GLRaV-3 (Jooste \& Goszczynski 2005; Turturo et al. 2005). Recently, sequences for more divergent strains of GLRaV-3 have been deposited in GenBank (www.ncbi.nlm.nih.gov). However, correlations between different strains of GLRaV-3 and pathogenicity have yet to be demonstrated.

\section{IMPACTS OF GLRaV-3 INFECTION IN THE VINEYARD}

Early research in New Zealand supported overseas evidence that grapevine leafroll disease (now predictably associated with GLRaV-3) adversely affected vine growth, yield, fruit colour and sugar content (McKissock 1964). Physiological symptoms of GLRaV-3 infected vines include degeneration of phloem cells in leaves, stems and fruit petioles. The degeneration is usually accompanied by an accumulation of starch in infected leaves (Hoefert \& Gifford 1967), which may be the feedback mechanism whereby photosynthetic activities are shut down. GLRaV-3 depresses photosynthesis by $25-65 \%$, depending on cultivar and environment, which directly affects growth and cropping (Cabaliero et al. 1997; Mannini et al. 1996). The appearance of characteristic disease symptoms depends on many factors, but GLRaV-3 depresses photosynthesis even in vines that do not reveal visual symptoms (Mannini et al. 1996, 1997). Viruses (including GLRaV-3) reduce cane weight and stem girth (Cabaleiro \& Segura 1996) and may reduce root growth (Hristov \& Abrasheva 2001), but large environmental variation makes the impacts difficult to quantify. The addition of foliar nutrients may alleviate the virus effects on photosynthesis (Sampol et al. 2003). GLRaV-3 infection may affect seasonal phenology through delayed budbreak (Woodham et al. 1984) and delayed berry maturity (Goheen 1981; 1988), although these effects are not well quantified - especially in New Zealand. Paradoxically there is some evidence that GLRaV-3 infection may increase vine longevity because the plant is less stressed as a result of reduced productivity over its lifetime (Borgo \& Michielini 2000). Most grape rootstocks, particularly American hybrids, do not show symptoms of leafroll even though they may carry the virus (Kovacs et al. 2001; Pietersen 2004), and GLRaV-3, possibly in conjunction with other viruses, may also result in graft incompatibility (Golino et al. 2002). A grapevine may be a 
host to several different viruses, which may interact to produce a range of symptoms. A GLRaV-3 plus fanleaf virus infection reduced number, area and mineral content of leaves (Sampol et al. 2003).

Evidence from a majority of studies around the world suggests that GLRaV-3 infected vines (of both white and red varieties) have reduced yield (e.g. Credi \& Babini 1997; Kovacs et al. 2001), lower fruit sugar levels (Borgo et al. 2003), higher titratable acidity (Credi \& Babini 1997) and lower berry anthocyanin levels (Guidoni et al. 2000) than healthy vines. In short, GLRaV-3 infected vines produce lower quality wine (Mannini et al. 1998).

\section{GLRaV-3 VECTORS AND THE ECOLOGY OF TRANSMISSION}

Mealybugs are small, hemi-metabolous, phloem-feeding insects. They excrete large quantities of honeydew upon which grow a number of black sootymould fungi. Twentysix species of mealybugs worldwide are known to feed on grapes, and 17 of these are considered to be pests of winegrapes (Anon. 2006). At least 10 of the 17 are known plant virus vectors. In New Zealand, 3 species of exotic mealybugs (but none of the ca 120 native species) feed on leaves, shoots, fruit and occasionally roots of grapevines. These species (long-tailed mealybug Pseudococcus longispinus, citrophilus mealybug $P$. calceolariae, and obscure mealybug $P$. viburni) develop through 2-3 generations a year, and numbers may increase greatly between spring and autumn (Charles 1981, 1982, 1993). All three mealybug species transmit GLRaV-3 (Petersen \& Charles 1997; Golino et al. 2002) and other grapevine viruses such as GVA and GVB, but it has been reported that transmission may depend on the presence of GLRaV-3 in the same grapevines (Engelbrecht \& Kasdorf 1990). Pseudoccoccus longispinus transmits GLRaV-5, but not GLRaV-1 or GLRaV-2.

Mealybug transmission of viruses of grapes and other plants is usually, if not always, semi-persistent. Mealybugs typically acquire virus in $0.25-12 \mathrm{~h}$ and retain virus for $12 \mathrm{~h}-5$ days. The virus may persist in a mealybug after post-acquisition moulting, but mealybugs may also quickly lose the ability to transmit virus after transfer. Transmission efficiency is variable (typically 15-25\%), and may be greater directly after post-acquisition feeding than after a fasting period. Temperature-mediated mealybug activity may be an important variable in transmission efficiency, and virus spread can occur through airborne dispersal of young, GLRaV-3 infected crawlers (Cabaleiro \& Segura 1997). Some grape cultivars are more susceptible to mealybugs than others (Walton 2001). However, studies of other plant/virus/mealybug interactions have shown that these relationships are not always predictable, so that, for example, both mealybug and virus are required to induce the disease symptoms of 'mealybug wilt of pineapple' (MWP). All mealybugs contain endosymbiotic bacteria, which probably synthesise amino acids essential for mealybug nutrition. Intriguingly, there is now some evidence from whitefly and aphid species that proteins produced by coccoid endosymbionts may play a crucial role in plant virus transmission (van den Heuval et al. 1994; Morin et al. 1999).

\section{MANAGEMENT OPTIONS IN VINEYARDS TO LIMIT GLRaV-3 INFECTION AND SPREAD}

The global distribution of graft transmissible grapevine viruses is largely due to the indiscriminate exchange of scion and rootstocks that occurred in the many years before plant viruses were known to exist. Surprisingly, there has been little international interest in measuring, or limiting, the extent of the virus in national vineyards - at least until recently. In some countries (e.g. USA and Spain) the role of mealybugs as vectors of GLRaV-3 has only very recently been realised, and control strategies are not yet widely in place. As a result, there is virtually no literature on management strategies to reduce or eliminate the spread of GLRaV-3, other than by reliance on certificated planting material.

The most directed efforts to manage the spread of GLRaV-3 across an industry have been established in South Africa (Pietersen 2004). Even here control systems are 
technical guidelines based on pragmatism rather than on in-depth scientific research. In principle the South African management strategies may be useful for New Zealand vineyards, but fundamental differences between the two countries mean that they cannot be simply duplicated here. Mealybug species are different; there is much heavier use of broad-spectrum insecticides in South Africa than in New Zealand; and several species of ants, not present in New Zealand, feed on honeydew and protect mealybugs from attack by their natural enemies.

Nevertheless, some aspects of the spread of the disease in South Africa are quite recognisable in New Zealand. The most common pattern of GLRaV-3 spread is that it occurs initially within rows between immediately adjacent infected vines before moving across rows and through vineyards as a result of mealybug dispersal by various combinations of air-currents, vineyard machinery and personnel. Removal of infected vines (roguing) may reduce the rate of spread of GLRaV-3 where the incidence of primary and secondary infected plants is low and where latent infection is not excessive, but it is not expected to be effective under all conditions. "Edge-effects" can indicate the spread of disease from other vineyards. Latent infection in asymptomatic vines is managed by spraying targeted insecticides.

In South Africa, good hygiene is considered especially important to minimise point sources of infection when replanting or top-working an old infected vineyard. However, the risks of spreading GLRaV-3 remain high, and top-working should never be promoted in New Zealand. Other management strategies include establishing large, isolated vineyards upwind from existing virus sources; and using shelterbelts to minimise invasion by dispersing mealybugs. Once planted, workers should keep tools clean and plan their daily schedule so that they visit the youngest, least infected blocks first.

Mealybug control is recognised in South Africa as the key to successful management and control of GLRaV-3, especially when vineyards are susceptible to sustained mealybug immigration. Mealybug pheromones (only available for Planococcus ficus at present) are new tools that help to reduce labour-intensive monitoring to determine the need for control actions (Walton et al. 2004). Mealybug numbers are usually monitored by a combination of physical examination of vines and pheromone traps. When required, pesticides should be applied to dormant vines when feasible, to minimise negative effects on natural enemies. However, there have been widespread control failures due to insecticide resistance, and the commonly used insecticides in South Africa are either not registered in New Zealand, or are not compatible with Sustainable WineGrowing New Zealand (SWNG) (de Wet \& Moores 2003). Biological control of $P$. ficus can provide effective control, but ant control (including Argentine ant) is crucial for effective mealybug biological control in South Africa. Appropriate cover crop and weed control strategies are also an important part of managing ants, mealybugs, natural enemies and hence the spread of GLRaV-3.

Effective control strategies in some other crops, where mealybugs are also vectors of viruses, include similar tactics and may help to illuminate GLRaV-3 management. Extensive studies on mealybug wilt of pineapples (MWP), African cassava mosaic virus (ACMV) and cocoa swollen shoot virus (CSSV) have all shown that the diseases and mealybug vectors are best controlled by various combinations of meristem propagation of virus-free plants, the development of transgenic plants, host plant resistance, mildstrain cross protection, mealybug biological control and cultural practices. A combination of several strategies is usually required for optimum control, and biological control of mealybugs is a key strategy across all crops. The presence of Argentine ant (now increasingly common in New Zealand vineyards) may disrupt biological control of Dysmicoccus brevipes and lead to an increased rate of MWP virus spread.

\section{DISCUSSION}

Although the symptoms of grapevine leafroll disease have been recognised in New Zealand for more than 100 years, an understanding of the causes of the disease has come slowly. Recognition that the disease was caused by a virus provided some early focus 
on the type of problem, even though initial emphasis on roguing (with no knowledge of a vector) did little to achieve control. In the 1960s to late 1970s, the small New Zealand wine industry was centred on American hybrid cultivars (which do not show marked symptoms of the disease), and there was little commercial incentive to develop a better understanding of the disease. When mealybugs were first discovered to be vectors of grapevine viruses, early studies to identify the viruses they could transmit and to measure transmission efficiency were hampered substantially by a lack of tools to (a) accurately identify the viruses themselves, and (b) measure low virus titres in both vines and mealybugs. Rapid advances in molecular biology and improved ELISA techniques delivered such tools, but only in the past 5-10 years has there been a reasonable understanding of the identity of the causal agents and vectors of grapevine leafroll disease. It is now clear that the disease known as grapevine leafroll disease in New Zealand is predominantly caused by the ampelovirus GLRaV-3, which is vectored between plants by any of the 2-3 species of mealybug vectors usually present in any vineyard. Other species of insect vectors and viruses in the Closteroviridae and Flexiviridae may also occasionally feature in grapevine disease transmission and epidemiology.

However, although this knowledge provides a basic understanding of how GLRaV-3 is transmitted, and hence how grapevine leafroll disease is spread, it does not successfully address the practical question of how to control or manage the disease across New Zealand's diverse wine industry. Understanding of the 'big picture' remains piecemeal. Molecular biologists have provided an improved understanding of virus taxonomy; virus epidemiologists have measured the spread of the disease in vineyards; entomologists have confirmed transmission in the laboratory; and grapevine physiologists have measured the effects of the disease on grapevines. But the literature on virus transmission by mealybugs in other plant species illustrates how the interactions between viruses, vectors and plants in nature may be unexpected, complex and interdependent. Some interactions that could be investigated in grapes include (a) the role of temperature, and mealybug endosymbionts, in virus transmission by mealybugs, (b) the effects of a virus complex within the plant on mealybug transmission and disease symptoms and (c) how plant resistance at the species and cultivar level, combined with plant nutrition and natural enemies, can affect the spread of disease.

The search of the global literature shows that there are no great advances elsewhere in the world that New Zealand can immediately appropriate to provide solutions for management of grapevine leafroll disease. Indeed, the biophysical environment that produces New Zealand wines is unique. New Zealand appears to be one of the very few countries that is warm enough for mealybugs to regularly reach high population densities, yet is insufficiently warm to provide sufficient additional ripening in summer to compensate for the effects of GLRaV-3 on grape quality at harvest. So, although South African grape growers have quite extensive management guidelines through technical data sheets, the mealybug vector (Planococccus ficus) is not present in New Zealand, and, in any case, it has a rather different biology from our species. In addition, some of the management options (e.g. use of broad spectrum insecticides) are not appropriate under SWNZ. It seems almost inevitable that the practical consequences of the virus - vine - vector interactions on management of grapevine leafroll disease in New Zealand will vary from region to region, and vineyard to vineyard.

Hence it would seem that an holistic (in keeping with SWNZ) and multi-disciplinary approach to controlling the disease in New Zealand will be the most successful. The disease is a complex one, and a full understanding of it will require input from plant virologists, entomologists, vine physiologists, pest controllers, vineyard managers, grapevine breeders/improvers and winemakers. Such a wide range of expertise will ensure that the factors behind the spread of the disease over time (its epidemiology) can be accurately determined, and will certainly be necessary to deliver effective management solutions over the course of decades. 


\section{ACKNOWLEDGEMENTS}

This paper summarises a review of the global impact and ecology of GLRaV-3, commissioned and funded by New Zealand Winegrowers Inc.

\section{REFERENCES}

Anon. 2006. Scale-Net. http://www.sel.barc.usda.gov/scalenet/query.htm (accessed 29 May 2006).

Bonfiglioli R, Stewart D 2005. Learning about leafroll 3. New Zealand Winegrower 9 (3): 88-90.

Bonfiglioli R, Hoskins N, Edwards F 2001. Grapevine leafroll viruses in New Zealand Viticulture - Fact Sheet and research update. Riversun Technical Bulletin 5.8 pp.

Borgo M, Michielini C 2000. Natural spread of grapevine leafroll on varieties and biotypes of Vitis vinifera. Rivista di Viticoltura e di Enologia 53(4): 3-13.

Borgo M, Angelini E, Flamini R 2003. Effects of grapevine leafroll associated virus 3 on main characteristics of three vineyards. L'enologo 3: 99-110.

Bragato R 1902. Report to the New Zealand Department of Agriculture: 451-5.

Cabaleiro C, Segura A 1996. Effect of grapevine leafroll-associated virus-3 in a commercial cv. Albarino vineyard. Investigacion Agraria: Produccion y Proteccion Vegetales 11(3): 451-463.

Cabaleiro C, Piñeiro A, Segura A 1997. Photosynthesis in grapevines infected with leafroll virus (GLRaV-3). 12th Meeting of the international council for the study of viruses and virus-like diseases of the grapevine (ICVG), Lisbon, Portugal. Pp. 153-154.

Cabaleiro C, Segura A 1997. Some characteristics of the transmission of grapevine leafroll associated virus 3 by Planococcus citri Risso. European Journal of Plant Pathology 103(4): 373-378.

Chamberlain EE 1967. Leafroll virus in the grapevines. Wine Review 4(3): 29-32.

Charles JG 1981. Distribution and life-history of the long-tailed mealybug, Pseudococcus longispinus (Homoptera: Pseudococcidae) in Auckland vineyards. New Zealand Journal of Zoology 8: 285-293.

Charles JG 1982. Economic damage and preliminary economic thresholds for mealybugs (Pseudococcus longispinus T.-T., Homoptera: Pseudococcidae) in Auckland vineyards. New Zealand Journal of Agricultural Research 25(3): 415-420.

Charles JG 1993. A survey of mealybugs and their natural enemies in horticultural crops in North Island, New Zealand, with implications for biological control. Biocontrol Science and Technology 3(4): 405-418.

Charles JG, Cohen D, Walker JTS, Forgie SA, Bell VA, Breen KC 2006. A review of Grapevine Leafroll associated Virus type $3(\mathrm{GLRaV}-3)$ for the New Zealand wine industry. Report to New Zealand Winegrowers. HortResearch Client Report No. 18447. HortResearch, Palmerston North, New Zealand. 101 pp.

Credi R, Babini AR 1997. Effects of virus and virus-like infections on growth, yield and fruit quality of Albana and Trebbiano Romagnolo grapevines. American Journal of Enology and Viticulture 48: 7-12.

de Wet O, Moores G 2003. Vine mealybug and chemical control: Is this the end of the road? http://www.wynboer.co.za/recentarticles/0803bugchem.php3 (accessed 29 May 2006).

Engelbrecht DJ, Kasdorf GGF 1990. Field spread of corky bark, fleck, leafroll and Shiraz decline diseases and associated viruses in South African grapevines. Phytophylactica 22(3): 347-354.

Goheen AC 1981. Grape Virus Diseases. In: Flaherty DL ed. Grape pest management. Agricultural Sciences Publications, University of California Berkeley, USA. Pp. 84-92.

Goheen AC 1988. Leafroll. In: Pearson RC, Goheen AC ed. Compendium of Grape Diseases. The American Phytopathological Society Press, St. Paul, Minnesota. USA. 93 pp. 
Golino DA, Sim ST, Gill R, Rowhani A 2002. California mealybugs can spread grapevine leafroll disease. California Agriculture 56(6): 196-201.

Guidoni S, Mannini F, Ferrandino A, Argamante N, di Stefano R 2000. Effect of virus status on leaf and berry phenolic compounds in two wine grapevine Vitis vinifera cultivars. Acta Horticulturae 526: 445-452.

Hoefert LL, Gifford EM 1967. Grapevine leafroll virus - history and anatomic effects. Hilgardia 38: 403-426.

Hristov I, Abrasheva P 2001. Effect of grapevine fanleaf virus and grapevine leafrollassociated virus 3 on vine plants under conditions of in vitro cultivation. Rastenievudni Nauki (Plant Science), Bulgaria 38(5-6): 269-274.

Jooste AEC, Goszczynski DE 2005. Single-strand conformation polymorphism (SSCP), cloning and sequencing reveal two major groups of divergent molecular variants of grapevine leafroll-associated virus 3 (GLRaV-3). Vitis 44: 39-43.

Kovacs LG, Hanami H, Fortenberry M, Kaps ML 2001. Latent infection by leafroll agent GLRaV-3 is linked to lower fruit quality in French-American hybrid grapevines Vidal blanc and St. Vincent. American Journal of Enology and Viticulture 52(3): 254-259.

La Notte P, Buzkan N, Choueiri E, Minafra A, Martelli GP 1997. Acquisition and transmission of grapevine virus A by the mealybug Pseudococcus longispinus. Journal of Plant Pathology 78(1): 79-85.

Le Ru B, Mitsipa A 2000. Influence of the host plant of the cassava mealybug Phenacoccus manihoti on life-history parameters of the predator Exochomus flaviventris. Entomologia Experimentalis et Applicata 95(2): 209-212.

McKissock A 1964. Two important virus diseases of grapevines in New Zealand. New Zealand Journal of Agricultural 108: 332-339.

Mannini F, Argamante N, Credi R 1996. Improvements in the quality of grapevine Nebbiolo clones obtained by sanitation. Acta Horticulturae 427: 319-324.

Mannini F, Guidoni S, Ferrandino A, Argamante N, Credi R 1997. Photosynthesis and grape composition of a Vitis vinifera clone after virus sanitation. 12th Meeting of the international council for the study of viruses and virus-like diseases of the grapevine (ICVG), Lisbon, Portugal. Pp. 155-156.

Mannini F, Gerbi V, Credi R 1998. Heat-treated virus-infected grapevine clones: Agronomical and enological modifications. Acta Horticulturae 473: 155-163.

Martelli G P, Agranovsky AA, Bar-Joseph M, Boscia D, Candresse T, Coutts RHA, Dolja VV, Falk BW, Gonsalves D, Jelkmann W, Karasev AV, Minafra A, Namba S, Vetten HJ, Wisler GC, Yoshikawa N 2002. The family Closteroviridae revised. Archives of Virology 147(10): 2039-2044.

Morin S, Ghanim M, Zeidan M, Czosnek H, Verbeek M, van den Heuvel JFJM 1999. A GroEL homologue from endosymbiotic bacteria of the whitefly Bemisia tabaci is implicated in the circulative transmission of tomato yellow leaf curl virus. Virology 256(1):75-84.

Nimmo-Bell 2005. Development of the New Zealand Grafted Grapevine Standard. A Nimmo-Bell Publication, Hastings, New Zealand. 32 pp.

Over de Linden AJ, Chamberlain EE 1970. Effect of grapevine leafroll virus on vine growth and fruit yield and quality. New Zealand Journal of Agricultural Research 13: 689-698.

Petersen CL, Charles JG 1997. Transmission of grapevine leafroll-associated closteroviruses by Pseudococcus longispinus and P. calceolariae. Plant Pathology 46(4): 509-515.

Petersen CL, Jordan D 1992. ELISA works well for the identification of leafroll. Proceedings of the New Zealand Grape and Wine Symposium: profit in the market, in the winery, in the vineyard. Christchurch, New Zealand. New Zealand Society for Viticulture and Oenology. Pp. 54-55. 
Pietersen G 2004. Spread of grapevine leafroll disease in South Africa - a difficult, but not insurmountable problem. http://www.wynboer.co.za/recentarticles/0406leaf. php3 (accessed 29 May 2006).

Sampol B, Bota J, Riera D, Medrano H, Flexas J 2003. Analysis of the virus-induced inhibition of photosynthesis in malmsey grapevines. New Phytologist 160: 403-412.

Thomas WT 1976. The impact of virus diseases on quality and yield in the vineyard. Wine Review 13 (2): 17-31.

Turturo C, Saldarelli P, Dong Y, Digiaro M, Minafra A, Savino V, Martelli GP 2005. Genetic variability and population structure of Grapevine leafroll-associated virus 3 isolates. Journal of General Virology 86: 217-224.

van den Heuval JFJM, Verbeek M, van der Wilk F 1994. Endosymbiotic bacteria associated with circulative transmission of potato leafroll virus by Myzus persicae. Journal of General Virology 75: 2559-2565.

Walton VM 2001. Mealybug: Biology and control strategies. http://www.wynboer. co.za/recentarticles/0301mealybug.php3 (accessed 29 May 2006).

Walton VM, Daane KM, Pringle KL 2004. Monitoring Planococcus ficus in South African vineyards with sex pheromone-baited traps. Crop Protection 23: 1089-1096.

Woodham RC, Antcliff AJ, Krake LR, Taylor RH 1984. Yield differences between sultana clones related to virus status and genetic factors. Vitis 23: 73-83. 